\title{
Intensive Pedestrian Survey Associated with the Enclave Gardens Development Project, San Antonio, Bexar County, Texas
}

Jennifer L. Thompson

Follow this and additional works at: https://scholarworks.sfasu.edu/ita

Part of the American Material Culture Commons, Archaeological Anthropology Commons, Environmental Studies Commons, Other American Studies Commons, Other Arts and Humanities Commons, Other History of Art, Architecture, and Archaeology Commons, and the United States History Commons

Tell us how this article helped you.

This Article is brought to you for free and open access by the Center for Regional Heritage Research at SFA ScholarWorks. It has been accepted for inclusion in Index of Texas Archaeology: Open Access Gray Literature from the Lone Star State by an authorized editor of SFA ScholarWorks. For more information, please contact cdsscholarworks@sfasu.edu. 
Intensive Pedestrian Survey Associated with the Enclave Gardens Development Project, San Antonio, Bexar County, Texas

\section{Creative Commons License}

\section{(c) (1) (8)}

This work is licensed under a Creative Commons Attribution-NonCommercial 4.0 International License 


\section{Intensive Pedestrian Survey Associated with the Enclave Gardens Development Project, San Antonio, Bexar County, Texas}

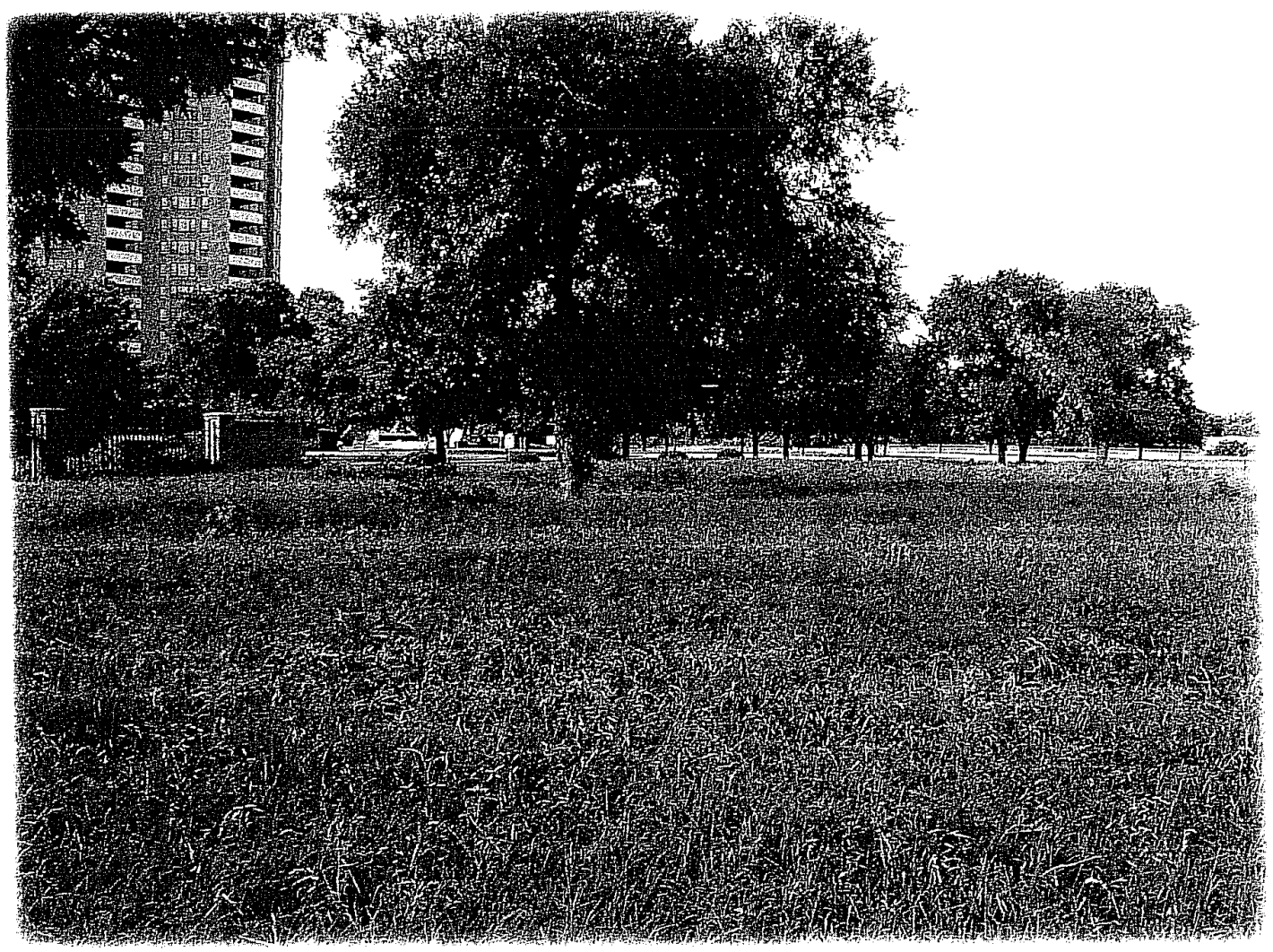

by

Jennifer L. Thompson

Prepared for:

Enclave Gardens, Ltd.

San Antonio, Texas

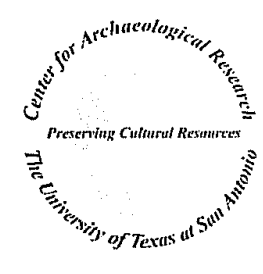

(C) July 2007
Prepared by:

Center for Archaeological Research

The University of Texas at San Antonio Archaeological Report, No. 375 


\section{Intensive Pedestrian Survey Associated With The Enclave Gardens DeVelopment Project, SAN ANTONIO, BEXAR COUnTy, TEXAS}

by

Jennifer L. Thompson

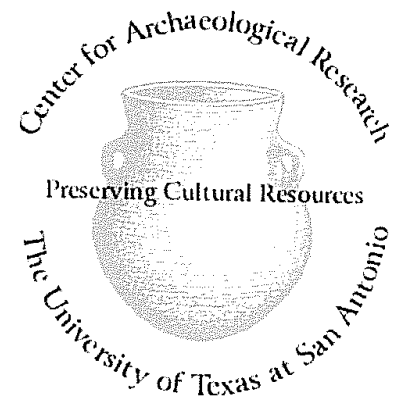

prepared for

Enclave Gardens, Ltd.

San Antonio, Texas

by

Center for Archaeological Research

The University of Texas at San Antonio

Archaeological Report Draft

(C) 2007 


\section{ABSTRACT}

On May 16, 2007, the Center for Archaeological Research at The University of Texas at San Antonio conducted an archaeological survey of six acres on the Enclave Garden property located in San Antonio, Bexar County, Texas. The archaeological work was completed for Enclave Gardens, Ltd., in cooperation with Hogan Real Estate Services who planned the construction of a housing development project on the property. Because Olmos Creek runs along the southern property boundary, the City Historic Preservation Office in San Antonio recommended archaeological investigations prior to construction in accordance with the San Antonio Uniform Development Code. There are no federal or state permits, properties or monies associated with this project therefore the Texas Antiquities Permit was not required.

Twelve shovel tests were placed across the property revealing water-worn gravels with little soil. All shovel tests contained modern trash or construction materials, though some prehistoric artifacts were found as well. These include three pieces of debitage, a core, and the base of an untypable projectile point. No features were identified during the survey and no sites were recorded. The natural landscape has been previously disturbed as seen in an aerial photograph from 1985, possibly associated with the re-channelization of Olmos Creek. Therefore, since no intact cultural deposits available for research were located, no further archaeological work is recommended on this property. We recommend the proposed development proceed as planned.

All artifacts collected during the project as well as all project-associated documentation are curated at the Center for Archaeological Research according to Texas Historical Commission guidelines. 


\section{TABLE OF CONTENTS}

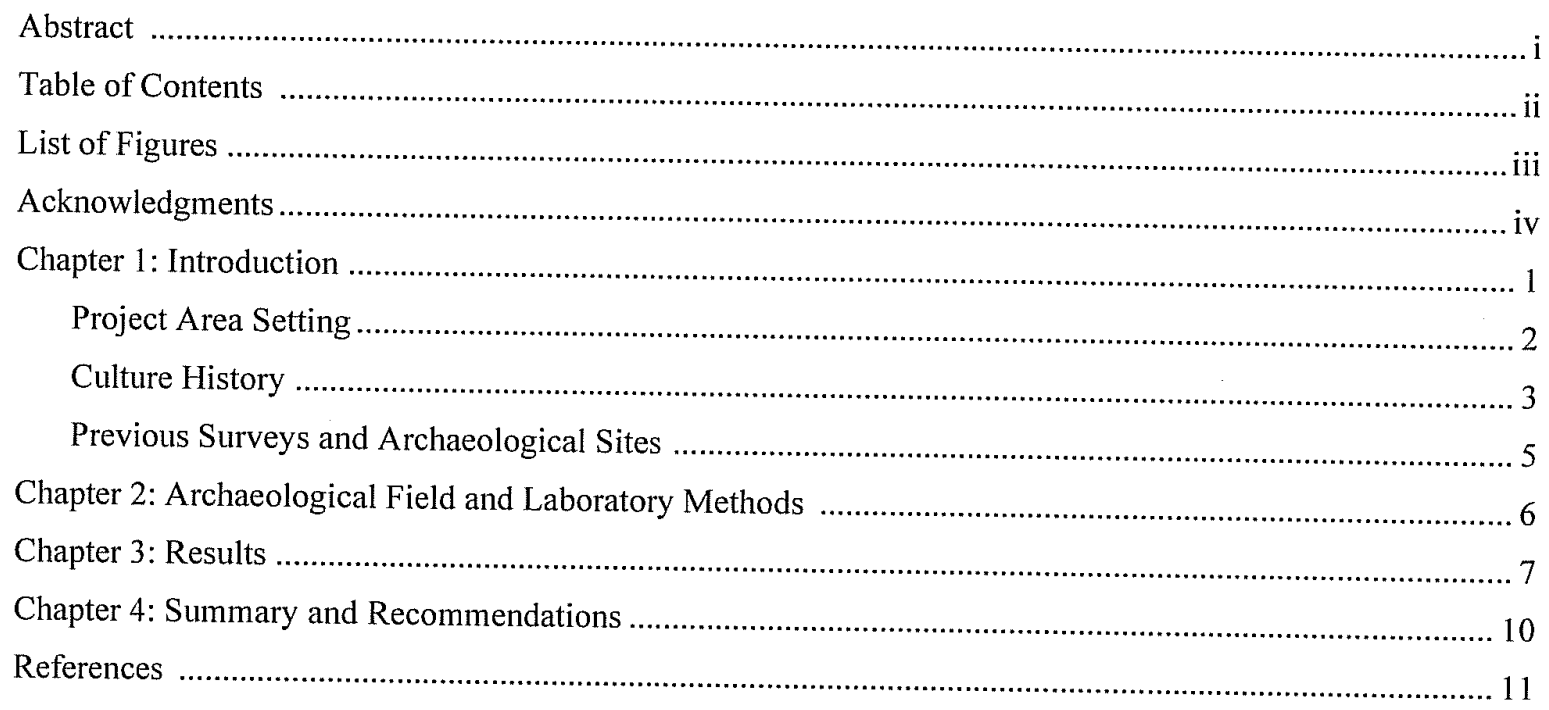




\section{LIST OF FIGURES}

Figure 1-1. The project area lies between Jackson Keller and Olmos Creek in San Antonio, Bexar, County, Texas.

Figure 1-2. A high-rise apartment building, The Enclave at 1550, sits on the eastern parcel. The manicured lawn in front of the building was tested.

Figure 1-3. The western parcel is undeveloped and covered in tall grasses.

Figure 3-1. Twelve shovel tests were excavated across the six-acre project area on two parcels.

Figure 3-2. One unidentifiable projectile point was excavated from a disturbed context with asphalt in Shovel Test 2.

Figure 3-3. A 1985 aerial shows the project area denuded of vegetation. 


\section{ACKNOWLEDGMENTS}

Several individuals aided in the successful completion of this project. The Center for Archaeological Research would like to thank Kay Hindes, archaeologist with the City of San Antonio Historic Preservation Office, for reviewing the Scope of Work and Steve Poppoon, who coordinated communications with Enclave Gardens, Ltd. and provided aerial photographs and plans of the project area. The survey was completed by a field crew that included Leonard Kemp, Joseph Thompson, and Jennifer Thompson. Jennifer Thompson served as the Project Archaeologist. Our GIS technical coordinator was Leonard Kemp who also drafted the figures used in the final report with Bruce Moses. Cynthia Muñoz, Antonia Figueroa, and Bruce Moses served as the technical editors. 


\section{CHAPTER 1: INTRODUCTION}

On May 16, 2007, the Center for Archaeological Research at The University of Texas at San Antonio (CAR-UTSA) conducted a pedestrian archaeological survey of six acres associated with the Enclave Gardens housing development project. The work was completed for Enclave Gardens, Ltd. in cooperation with Hogan Real Estate Services, who propose to build a housing development on 8.2 acres between Jackson Keller Road and Olmos Creek in San Antonio, Bexar, County, Texas (Figure 1-1). This area can be seen on the Castle Hills USGS topographic quadrangle. Because the property abuts Olmos Creek, the City Historic Preservation Office (CHPO) recommended archaeological investigations prior to construction in accordance with the San Antonio Uniform Development Code and the Antiquities Code of Texas. Approximately 2.0 of the 8.0 acres proposed for development were previously disturbed by the old Olmos Creek channel prior to its artificial channelization to alleviate flooding of area that occurred between 1977 and 1985. Therefore, CAR contracted with Enclave Gardens, Ltd. to conduct an intensive pedestrian archaeological survey of approximately 6.0 acres north of Olmos Creek.

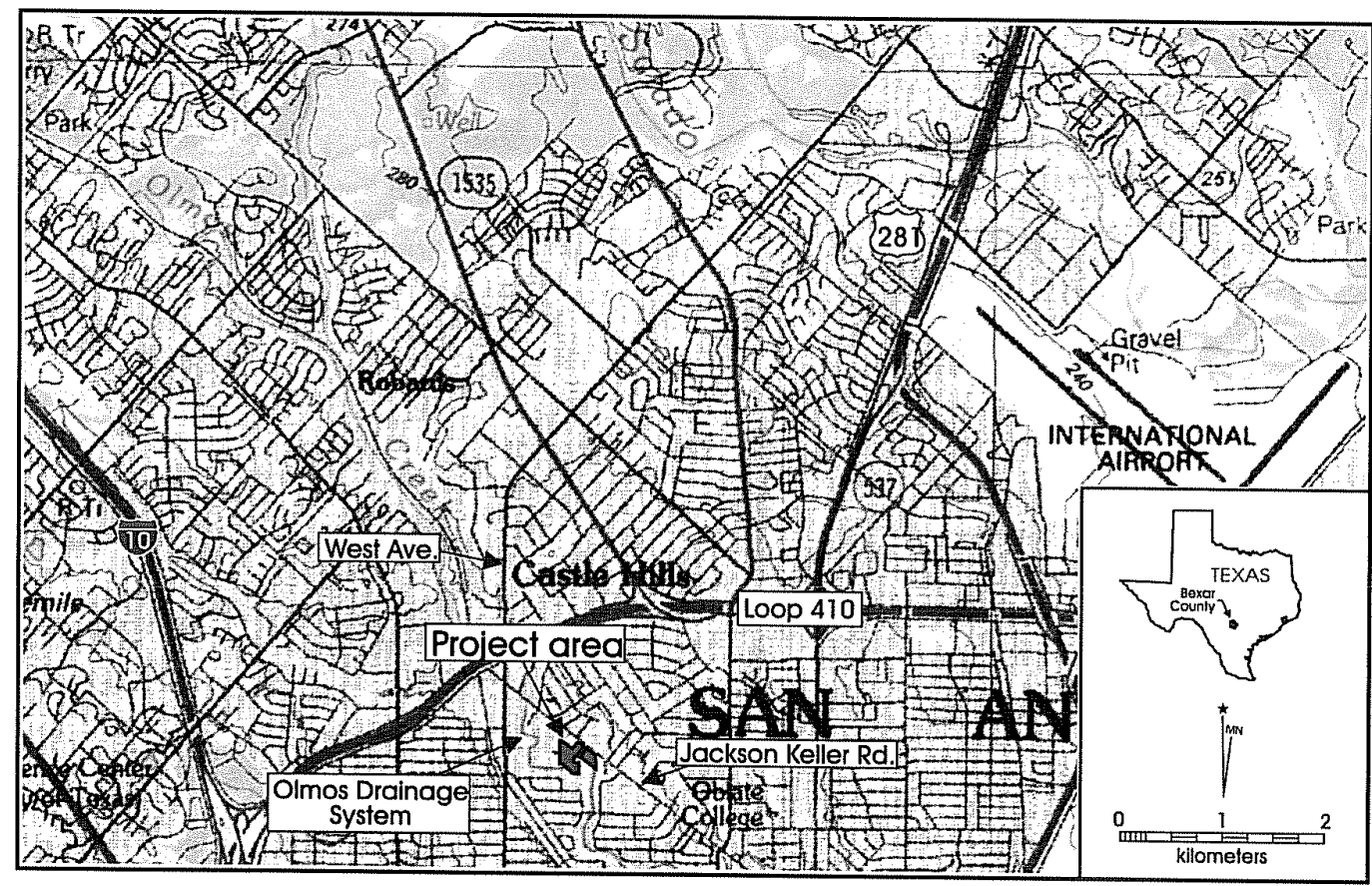

Figure 1-1. The project area lies between Jackson Keller and Olmos Creek in San Antonio, Bexar County, Texas. 
The CAR performed the necessary tasks to meet the CHPO's requirements. The current project does not require a Texas Antiquities Committee Permit because no federal or state owned land or funds will be used during development and no other state permits will be required to complete the planned development. CAR conducted a document search of the property for known archaeological sites in the vicinity and previous archaeological studies conducted on the property or within one mile of the location. After completing the background search, CAR proceeded with fieldwork that included a pedestrian survey using shovel testing and surface inspection to meet the Minimum Standards set forth by the Texas Historical Commission.

\section{Project Area Setting}

The survey area lies within an urban residential area surrounded by subdivisions and multi-family housing units just south of Loop 410 on Jackson Keller Ave. The project area consists of two parcels. The eastern parcel is a manicured lawn in front of The Enclave at 1550, a high-rise apartment building at the southeast corner of the lot (Figure 1-2). The western parcel is across a limited access driveway from the apartment building and is covered in tall grasses (Figure 1-3). Trees line the driveway up to the apartment tower.

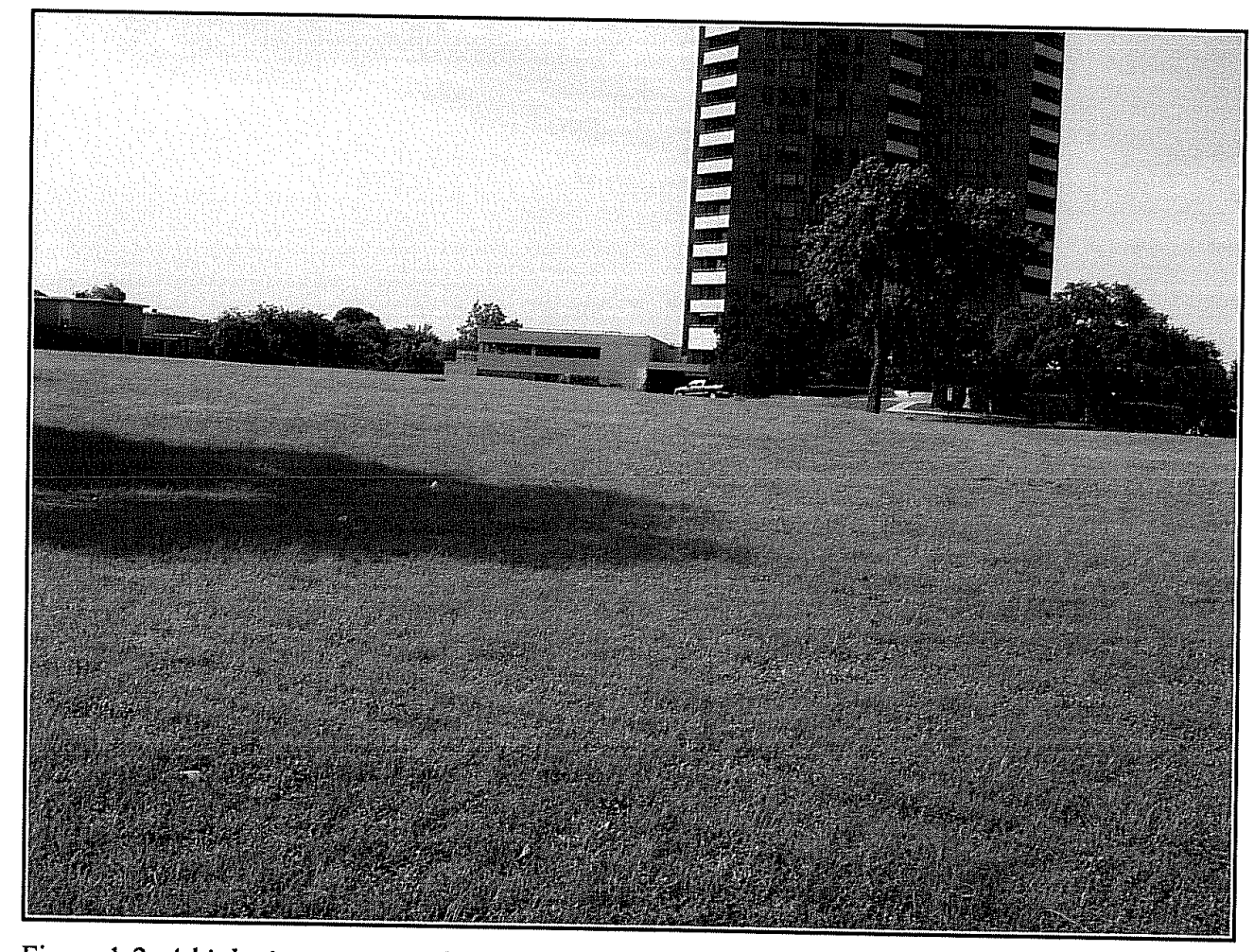

Figure 1-2. A high-rise apartment building. The Enclave at 1550, sits on the eastern parcel. The manicured lawn in front of the building was tested. 


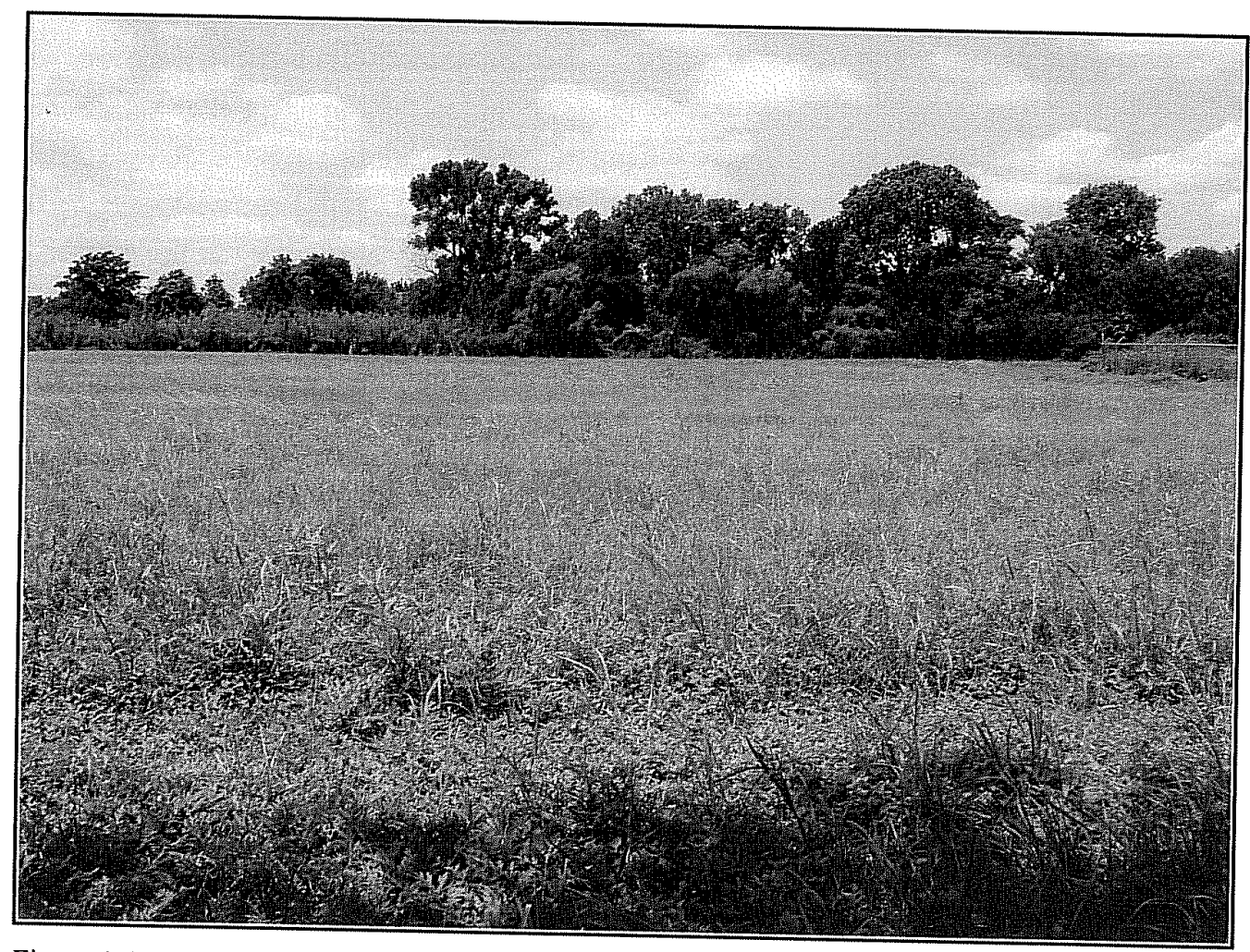

Figure 1-3. The western parcel is undeveloped and covered in tall grasses.

Olmos Creek bounds the southern extent of the project area. The creek has many recorded sites along its former channels though no sites are recorded near the Enclave development area under investigation. Olmos Creek flows from northwest San Antonio approximately 15 miles southeast to the San Antonio River near downtown. The stream is dammed midway through its course by the Olmos Dam. A section of the natural channel once ran through the project area but has been altered to run south of its previous path. Historically, the creek was prone to flooding and therefore much of the current project area was likely impacted by the meandering channel and overbank deposits from historic and prehistoric floods as well as the more recent channelization efforts.

\section{Culture History}

Humans have inhabited South Texas for nearly 12,000 years, leading a nomadic lifestyle of hunting and gathering. Archaeologists generally divide this time span into four periods defined by changes in material culture that have been dated in the archaeological record. For Texas, these divisions are Paleoindian, Archaic, Late Prehistoric, and Historic. Other studies describe these periods in detail and should serve as a more thorough description for Central Texas (see Collins 
2004). A brief overview of prehistoric cultures is described here.

The Paleoindian Period is the earliest cultural tradition defined for North America and spans from 11,200 to 8800 B.P. at the end of the Pleistocene. Humans living during the Paleoindian Period were nomadic hunter-gatherers who survived by hunting large and small game and collecting plant foods similar to their descendants. They hunted with spears tipped with lanceolate shaped, fluted projectile points. The best-documented cultures are associated with the Clovis horizon that also is present at sites around the country and in Central Texas. Much of what we infer about the Clovis horizon comes from data elsewhere. The Folsom horizon followed the Clovis horizon. Sites in Central Texas with a Folsom component also contain an abundance of bison remains suggesting that bison may have been specifically targeted or plentiful game.

The Archaic Period began 9000 years ago and continued for 7500 years. Stemmed projectile points begin to appear in the archaeological record along with some lanceolate point forms. The Archaic also saw the rise of "hot rock" cooking and the use of earth ovens. These were used primarily to cook plant bulbs. Groundstone tools are found in greater numbers in the archaeological inventories dating to this time. These tools, used primarily for processing plant foods, along with the earth ovens, suggest that human populations were growing and developing new technologies in order to more efficiently use a variety of plant and animals resources for sustenance. Projectile point forms changed throughout the period and various forms have been used to divide the Archaic further into the Early, Middle, and Late sub-periods.

The Late Prehistoric Period begins with the widespread use of the bow and arrow, approximately 1200 B.P. The use of the bow and arrow may have been a response to changing food availability from large game, such as bison, to increasing dependence of smaller game, like deer, that are more easily killed with an arrow than a spear. The time may have also been marked by some violence between different social groups, possibly over territory, as mortuary sites dating to this time contain burials of people who succumbed to death from unnatural causes. Ceramics also begin to appear in the archaeological record of Central and South Texas during the last part of the Late Prehistoric. Ceramics like bone-tempered Leon Plain are associated with the Toyah phase and are often found with large unifacial tools, Perdiz arrow points, and bison remains leading most scholars to believe that bison were an important part of the subsistence strategy of hunter gatherers during the later part of the Late Prehistoric.

The Historic period begins with the written documentation of historical events that began with European Contact in the New World. This contact resulted in tremendous impact to the 
indigenous cultures in place that ultimately caused the displacement and enculturation of Native Peoples. The earliest explorers to the area were the Spanish who made forays into Texas as early as the 1500 s but did not begin settling the area until the 1600s. Mission settlements occurred in Bexar County in the 1700s, where Native Americans were targeted for Christian conversion and Spanish indoctrination.

Historic preservation law generally considers any property, artifact, or event older than 50 years "historic" and applicable to a level of study if preservation is threatened; therefore, the end of the historic periods ends 50 years prior to the date of the study.

\section{Previous Surveys and Archaeological Sites}

No archaeological surveys are recorded in the Texas Archaeological Sites Atlas for the study area and no historical or prehistoric archaeological sites have been recorded there. Within a mile to the north of the study area, 41BX1152 was recorded. Limited testing here included one shovel test and three backhoe trenches, performed in 1995 by member of TxDOT. Human skeletal elements, a 5-x-5-m burned rock scatter, dart projectile points, and other stone tools and faunal remains were recovered from the site. Because the site could not be accurately dated, no further archaeological excavations were recommended for the site, though the data collected was deemed valuable for future researchers interested in burned rock midden sites (see Prilliman et al. 1997).

According to the Texas Archaeological Sites Atlas, the only survey in the vicinity was performed for San Antonio Water Systems and reported by Sylvia Reyna of GMI in 2004. The survey area followed the Olmos Creek and recorded no sites along the creek near the current study area. 


\section{CHAPTER 2: ARCHAEOLOGICAL FIELD AND LABORATORY METHODS}

Based on the survey area not impacted by channelization ( 6 acres), 12 shovel tests are required to fulfill the THC minimum survey standards, at a density of one every two acres. Shovel test locations were proposed across a 50-meter grid, avoiding the former Olmos Creek channel.

Shovel tests measured $30 \mathrm{~cm}$ in diameter, and when possible, excavated to a depth of $60 \mathrm{~cm}$ in 10-cm increments. All soil from each level was screened through 1/4-inch hardware cloth. All collected artifacts were recorded with appropriate provenience for laboratory processing, analysis, and curation. A shovel test form was completed for every excavated shovel test. Data collected from each shovel test included the final excavation depth, a tally of all materials recovered from each 10-cm level, and a brief soil description (texture, consistence, Munsell color, inclusions). The location of every shovel test was recorded with Trimble Geo XT GPS units. Shovel test locations were also sketched onto aerial photographs as a backup to GPS provenience information.

For the purposes of this survey, an archaeological site must contain a certain number of cultural materials or features that at least 50 years old within a given area. The definition of a site used for this project is as follows: (1) Five or more surface artifacts within a 15-meter radius, (2) a single cultural features such as a hearth, observed on the surface or within a shovel test, (3) a positive shovel test containing at least three artifacts within a single $10-\mathrm{cm}$ level, (4) a positive shovel test containing at least five total artifacts or (5) two positive shovel tests located within 30 meters of each other.

All cultural materials and records obtained or generated during the project were prepared in accordance with federal regulation 36 CFR part 79 and THC requirements for State Held-in-Trust collections. Additionally, the materials were curated in accordance with current CAR guidelines. Artifacts processed in the CAR laboratory were washed, air-dried, and stored in 4-mm zip locking archival-quality bags. Acid-free labels were placed in all artifact bags. Each label contains provenience information and a corresponding lot number written in archival ink, with pencil or laser printed. Digital photographs were printed on acid-free paper, labeled with archival appropriate materials, and placed in archival-quality sleeves. All field forms were completed with pencil. All collected materials are housed at CAR. 


\section{CHAPTER 3: RESULTS}

Twelve shovel tests were excavated across the six-acre project area on two parcels (Figure 3-1). Nine shovel tests were excavated on the west parcel. Asphalt, concrete, glass and other modern materials were found within the excavations of all these up to $60 \mathrm{cmbs}$. Asphalt was visible at the surface in the west parcel near Shovel Tests 5 and 7 . These tests were relocated in efforts to find a less disturbed area but were unsuccessful. This area was perhaps impacted by the channelization of the creek or the paving of the cul-de-sac at the end of the Enclave at 1550 driveway.

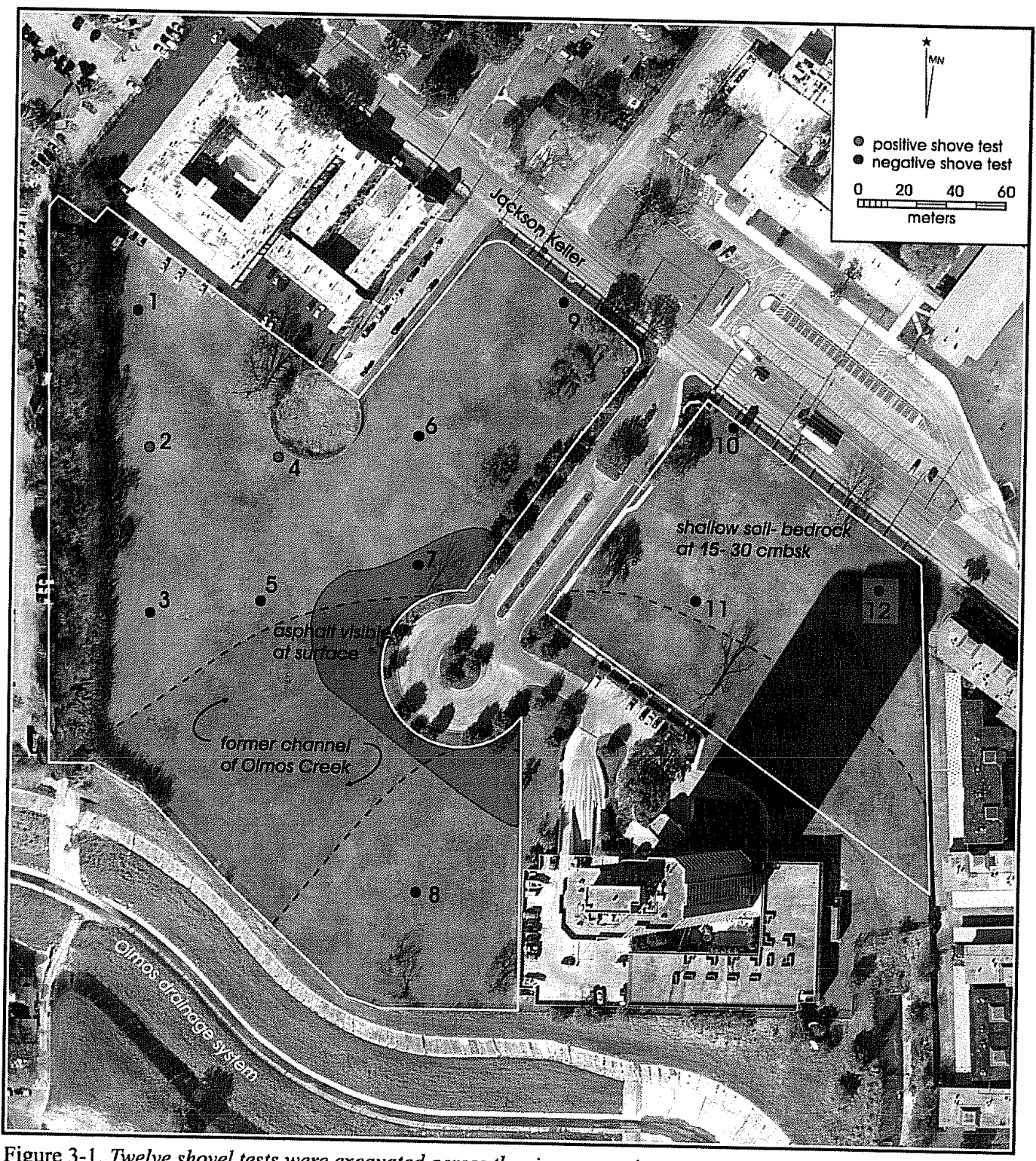

Figure 3-1. Twelve shovel tests were excavated across the six-acre project area on two parcels. 
Prehistoric cultural materials were recovered from two shovel tests, though they were found in disturbed contexts. One unidentifiable projectile point (Figure 3-2) was found in Shovel Test 2 at approximately $35 \mathrm{cmbs}$, along with asphalt. Shovel Test 4 contained two pieces of debitage and one core up to $40 \mathrm{cmbs}$, also with construction materials.

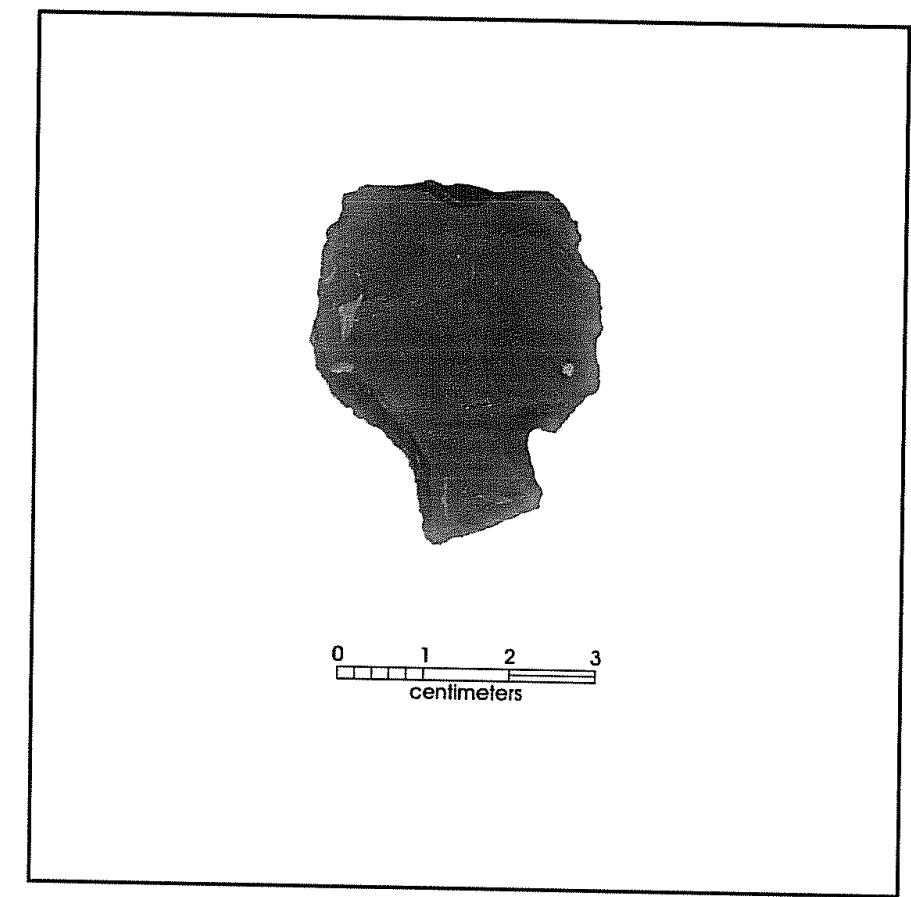

Figure 3-2. One unidentifiable projectile point was excavated from a disturbed context with asphalt in Shovel Test 2.

Three shovel tests were placed in the eastern parcel. Shovel Tests 10-12 could not be excavated to $60 \mathrm{cmbs}$ because weathered limestone bedrock was encountered at shallow depths between 15 and $30 \mathrm{cmbs}$. No artifacts were recovered from the upper levels of these tests. Concrete and asphalt construction materials were observed in Shovel Test 11.

Soils in the area historically were within the Lewisville Soil Series but little is left of the original stratigraphy now. Generally, this series consists of three zones of silty clay with a high percentage of lime approximately $60 \mathrm{in}$. thick overlaying deep beds of water-rounded gravels (Taylor et al. 1966). We observed very little soil and lots of water-rounded gravels and deteriorating limestone over bedrock/large limestone boulders. Aerials from 1985 (Figure 3-3) show the project area was stripped of vegetation perhaps because of the creek channelization. This activity may also have removed the soils, as well as any archaeological sites, overlying the gravel that lies directly below the rootbed today. 


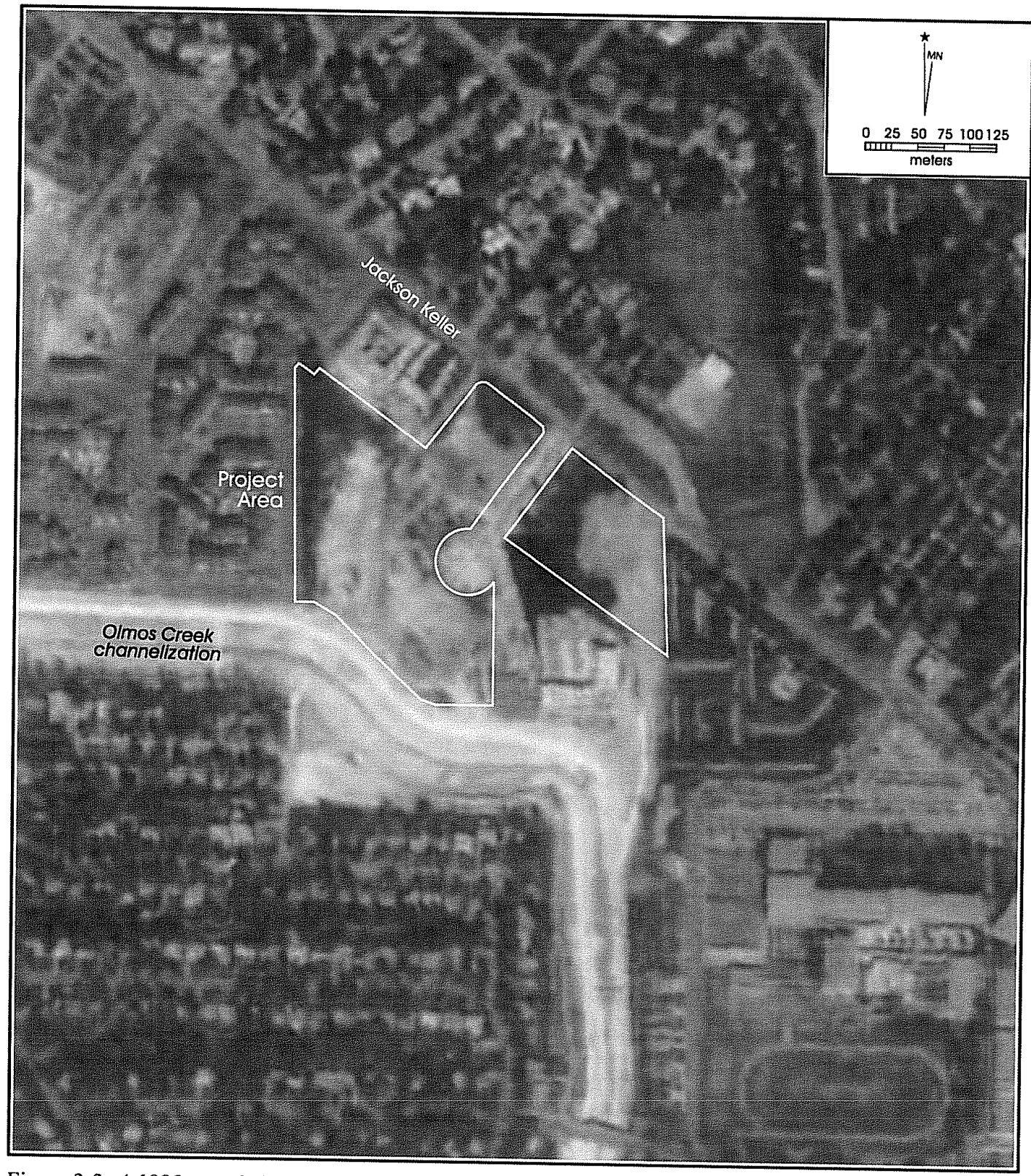

Figure 3-3. A 1985 aerial shows the project area denuded of vegetation. 


\section{CHAPTER 4: SUMMARY AND RECOMMENDATIONS}

The Center for Archaeological Research at The University of Texas at San Antonio conducted an archaeological survey of six acres on the Enclave Garden property located in San Antonio on May 16, 2007. The archaeological work was completed for Enclave Gardens, Ltd. in cooperation with Hogan Real Estate Services who have planned a housing development project on the property. The CHPO recommended archaeological investigations prior to construction because of the land's proximity to Olmos Creek, along which many sites exist, and in accordance with the city's Uniform Development Code. There are no federal or state permits, properties or monies associated with this project therefore the Texas Antiquities Permit was not required.

CAR excavated twelve shovel tests within the six-acre project area. The tests reveal water-worn gravels with little soil. All shovel tests contained signs of disturbance consisting of the presence of modern trash and construction materials. A few prehistoric artifacts were encountered in disturbed contexts. These consisted of three fragments of debitage, one core, and the base of an untypable projectile point. No features were identified during the survey and no sites were recorded. The natural landscape has been previously disturbed as seen in the aerial photograph from 1985, possibly associated with the re-channelization of Olmos Creek, which occurred between 1978 and 1985. Therefore, since no intact cultural deposits were identified, we find no archaeological research potential on the property. CAR recommends that no further archaeological work is necessary, and the proposed development project proceed as planned.

All artifacts collected during the project as well as all project-associated documentation are curated at the Center for Archaeological Research according to Texas Historical Commission guidelines. 


\section{REFERENCES}

\section{Collins, M. B.}

2004 Archeology in Central Texas. In The Prehistory of Texas, edited by T.K. Perttula, pp. 205-265. Texas A\&M University Press, College Station.

Prilliman, K. L., D. W. Driver, M. B. Collins, and O. F. Huffman 1997 Archeological Testing at Site $41 B X 1152$ in the Olmos Creek Channelization Project,
Castle Hills, Texas.

Taylor, F. B., R. B. Hailey, and D. L. Richmond

1966 Soil Survey of Bexar County, Texas. U.S. Department of Agriculture Soil Conservation Service. The Soil Conservation Service, Washington, D.C. 